Отримано: 8 травня 2018 р.

Прорецензовано: 29 травня 2018 р.

Прийнято до друку: 1 червня 2018 р.

e-mail: valerymykhaylenko@i.ua

DOI: $10.25264 / 2519-2558-2018-2(70)-28-30$
Mykhaylenko V. Internationalisms: contrastive semantics. Наукові записки Національного університету «Острозька академія»: серія «Філологія». Острог : Вид-во НаУОА, 2018. Вип. 2(70), червень. С. 28-30.

\author{
Valery Mykhaylenko, \\ Doctor of Philology, professor \\ Institute of International Relations and Social Studies, MAUP, Kyiv
}

\title{
INTERNATIONALISMS: CONTRASTIVE SEMANTICS
}

The present paper is concentrated on contrastive semantics of internationalisms in English and Ukrainian discourse of economics. Originally, they belong to borrowings from the common donor language with a constant meaning but phonetically and morphologically adapted by the receptor languages. Borrowed from the donor language they are used in the receptor language without translation. We suggest a five-step algorithm of investigating them (1) to determine the primary source of borrowings, and outline their lexical meaning development; (2) to reveal their current lexical meaning; (3) to specify nucleus and periphery components in the internationalism lexical meaning when used in the economics discourse; (4) to reveal distributional characteristics of internationalisms in the economics discourse; (5) to introduce the corpus analysis to illustrate their frequency in various discourse registers which may help the choice of the term in translation. The receptor language selects an internationalism and integrates it in accordance with its own intra- and extra-linguistic standards The crosscultural aspect of internationalisms is very significant for the communities and nations on the way of mutual understanding. Accordingly, their cross-cultural significance must be in focus of an interdisciplinary investigation, for it is vital for the Global language development, politics, economy, and culture.

Key words: internationalism, borrowing, discourse, cross-cultural, etymology, valency.

\section{Михайленко Валерій Васильович,}

доктор філології, професор

Інститут міжнародних відносин і сочіальних наук МАУП, Київ

\section{ІНТЕНАЦІОНАЛІЗМИ: КОНТРАСТИВНА СЕМАНТИКА}

Стаття присвячена контрастивній семантиці інтернаціоналізмів в англійському та украӥнському економічному дискурсі. Інтернаціоналізми - запозичення зі спільної мови-донора, щуо зберігають його первинне значення, однак, мова-рецептор проводить відбір та адаптацію інтернаціоналізмов згідно своим інтра- та екстра-лінгвістичним стандартам. Дослідження міжкультурного значення інтернаціоналізмів нагальне завдання для глобального розвитку мови, політики, економіки та культури.

Ключові слова: інтернаціоналізм, запозичення, дискурс, міжкультурний, походження, сполучуваність.

\author{
Михайленко Валерий Васильевич, \\ доктор филологии, професор \\ Институт международных отношений и сочиальных наук, МАУП, Киев
}

\section{ИНТЕРНАЦИОНАЛИЗМЫ: КОНТРАСТИВНАЯ СЕМАНТИКА}

Данная статья посвячена контрастивной семантике интернационализмв в английском и украинском дискурсе экономики. Интернаиионализмы --заимствования из общего языка-донора, сохраняюшие его исконное значение, однако, язык-реиептор производит отбор и адаптацію интернационализмов согласно свойм интра- и екстра-лингвитическим стандартам. Исследование их межкультурного значения - безотлагательная задача для успешного развития глобальных аспектов языка, политики, экономики и культуры.

Ключевые слова: интернационализм, заимствование, дискурс, межкультурный, происхождение, дистрибуция.

PRELIMEINARIES. The present paper is concentrated on contrastive semantics of internationalisms in the English and Ukrainian discourse of economics. Internationalisms are loan words registered in several languages Originally, they belong to borrowings from the common donor language with a constant meaning but phonetically and morphologically adapted. [16, p. 57]. Borrowings taken from one language and used in another language are traditionally grouped into loanwords and loan translations [15, p.67-68, 285]. The borrowings must be in focus of an interdisciplinary investigation, for it is vital for the Global language development, politics, economy, and culture [19, p.64-69; 4].

1) Loanwords functioning as internationalisms constitute the object of our investigation: they are taken from another language and used without translation. They have a specific meaning that usually does not otherwise exist in a receptor language. Due to the level of their assimilation the loans undergo some alteration in orthography or phonetics, but, in most cases, they preserve their original meaning of the donor language. A huge amount of loanwords are so assimilated in the English language or any other languages that they are treated as native ones. Internationalisms are units borrowed from one and the same source language by at least three genealogically different languages in the same or similar lingual form and identical meaning, for instance, the internationalism personnel is registered in Engl./Fr. personnel, Ukr./Rus./Bulg. персонал, Blr. персонал, Sw./Sp./ Rum. /Cz. /Est. personal, Pol. personel, It. personale, Let. personāls, Lit. personalas and others. The given units go back to French personnel (a contrastive term to matériel), noun use of personnel (adj.) "personal," developed from Old French personel, see personal, which developed in late 14c., "pertaining to the self," from Old French personal (12c. Modern French personnel), from Late Latin personalis" pertaining to a person." Its meaning "aimed at some particular person" (usually in a hostile manner) first attested in 1610s. The unit may change morphologically or phonetically but preserves the dominant component in its lexical meaning like Modern English economic term: 
"employees of an organization; or human resources (see H.R.) division of an organization" (Business Dictionary), English personnel department corresponds to Ukrainian відділ кадрів. The fact is that Ukr. персонал of an enterprise or an institution means a set of employees of various professions and qualifications.; while the term кадри refers to permanent staff qualified as a rule.. No doubt, this is not an illustration of translation it is rather a case of "substitution of one loan by another loan word due to the crosscultural difference [cf. 11, p.47-50]. Let's take the loan functioning in Ukrainian директор “керівник підприємства, установи або навчального закладу» came from French Яthe ing-form as subject: Passing a law about equal rights doesn't necessarily mean that women get them. There's no denying that;

2) the ing-form as predicative: The important part is helping people. To read his novels was like swimming in a lake;

3) the ing-form as predicate: What about going to London? How about seeing what they are doing now? But letting him do it!;

4) the ing-form as part of a compound verbal predicate: They all sat around feeling very proud. In this function the ing-form is lexically dependent and is used after verbs denoting motion or position: to come, to go, to go out/about/round/around, to lie, to sit, to sit around/ round, to stand, to stand around/ round, to disappear;

5) the ing-form as a second action accompanying the action of the predicate verb. The subject of the ing-form is the same as the subject of the sentence: They ran up the stairs brimming with excitement. Having duly arrived in Scotland, he took a train the next day. Miss Smith was in her office typing;

6) the ing-form as object: English grammar is very difficult and few writers have avoided making mistakes in it. The ing-form is used as object to a direct or prepositional verb. It is lexically dependent. For example: Let's get down to signing the papers;

7) the ing-form as subjective predicative is lexically dependent after a number of verbs in the Passive: catch, find, hear, leave, notice, report, see, set, show, and watch. For example: The baby was found sitting on the floor. Here also belong a few verbs after which the ing-form is introduced by as: At school Janet and I were considered as going together;

8) the ing-form as objective predicative is lexically dependent after a number of transitive verbs in the Active followed by an object which is expressed by a noun or a pronoun. The following are the most frequently used verbs taking a direct object: call, catch, discover, feel, find, hear, get, imagine, keep, leave, like, dislike, notice, picture, see, send, set, stop, watch, want. For example: I felt him looking at me;

9) the ing-form as adverbial modifier to a verb. In this case it is preceded by a conjunction or a preposition which lend it adverbial meanings, such as time, concession, condition, attending circumstances, manner, cause, and some others. The ing-form may be preceded by the conjunctions while, when, once, if, as though, as if, though, than, as well as and correlative conjunctions as...as, not so... as. For example: He continued to speak while walking down the path. He listened as though brooding. Nothing is so dangerous as being too modern;

10) the ing-form as a part of an absolute construction where the ing-form may have a subject of its own: His study was a nice room with books lining the walls. She looked at him, her face radiantly smiling. Absolute constructions denote a second action and acquire adverbial meanings: A room lit up on the third storey, someone working late;

11) the ing-form as attribute. The ing-form may immediately precede its head-noun: a barking dog, the setting sun, trembling hands, the burning questions, a creaking laugh. It is typical of the ing-form in this function to become adjectivised: the idea of action is absent;

12) the ing-form as parenthesis tends to become a set phrase: Secrets, generally speaking, are not very well kept nowadays. It goes without saying that healthy men are happier than sick men [6, p. 169-190].

The gerund is used in the following cases:

1) as the subject, object and complement of a sentence: Playing golf helps me relax; I find watching it on television rather boring;

2) after prepositions: We thought about going to France this year;

3) after the following expressions: have difficulty/ problems, there's no/ little point, it's no good/ use, it's (not) worth: It's no use asking him - he won't know the answer;

4) after the following verbs: admit, adore, advise, anticipate, appreciate, avoid, can't help, can't stand, consider, delay, deny, detest, dislike, dread, enjoy, feel like, give up, imagine, involve, keep, (don't) mind, miss, postpone, practice, prevent, propose, put off, recommend, resent, resist, risk, suggest: I resent having to do all the housework myself. We appreciate your coming to tell us so quickly;

5) after the following verbs + the preposition to: adapt/ adjust to, admit to, confess to, get round to, get used to, look forward to, object to: She confessed to being surprised by his success [8, p. 218].

The following verbs can be followed by the gerund or the to-infinitive with no change in meaning: begin, can't bear, continue, hate, intend, like, love, prefer and start [8, p. 218]. For example, She suddenly started singing/ to sing. The infinitive is common for specific situations and the gerund is used to describe an event in general. Compare: I hate to say this, but your breath smells; I hate getting up early in the morning. The verbs like, love, hate, prefer have little, if any, difference in meaning when used with the to-infinitive or the ing-form [9, p. 210].

The verbs that can be used with both the to-infinitive and the ing-form with a change in meaning are as follows: forget, remember, try, go on, mean, need, and stop [9, p. 210]. The gerund that is preceded by the verbs forget, regret, remember, stop is used when the act that is expressed by the gerund comes first: I distinctly remember posting the letter yesterday. The to-infinitive follows remember, forget, regret, stop when the act expressed by the infinitive comes second: I must remember to post this letter later [8, p. 218]. If the leading verbs remember, forget, regret, stop express the first action in time, the next action is represented by the to-infinitive.

The model try + to do is used when it means 'attempt to do'; the model try + doing is used when it means 'experiment with doing'. For example, I am trying to sleep and try using earplugs. The model mean + to do is used when it means 'intend to do'; the model try + doing is used when it means 'involve doing' [8, p. 218]. Compare: I have been meaning to write you for ages; Changing jobs also means changing house. So the models verb + to do and verb + doing encapsulate the meaning.

In the case of gerund complements, the verbs forget, remember, try usually mean that the subject of the main clause completed or fulfilled an action, whereas in the case of infinitive complements, they usually denote future unfulfilled action of the subject of the main clause [1, p. 648-649]. For example: 
1. He forgot to call his parents. (He didn't call his parents because of his forgetfulness.) He forgot calling his parent. (He didn't remember if he had called his parents.)

2. We must remember to feed the cat. (Remember what you have to do.) I remember coming here when I was young. (To recall a previous action.)

3. I should try to eat more fruit. (You should make an effort/ an attempt to eat more fruit.) You should try eating more fruit. (You should see if eating more fruit will help you. Do an experiment in order to see what will happen) [10].

The verbs like, love, enjoy, relish, fancy, appreciate, want, wish, desire, long, yearn, hanker, pine, hunger and thirst are used with the infinitive and the gerund as complements. The verbs like and love admit both forms of complementation, whereas the other verbs in this semantic group are construed either with the gerund (enjoy, relish, fancy, appreciate) or with the infinitive (want, wish, desire, long, yearn, hanker, pine, hunger, thirst). Verbs such as like and love are capable of evoking an enjoyment and a desire, inclination. Enjoyment implies coincidence in time between the liking and the event liked. The verbs like and love have the far greater frequency of the to-infinitive as compared to the gerund in British and American English. Researcher P. Duffley uses two types of selection criteria: structural rules, such as the restriction of the verb dislike to construal with only ing-complements, and semantic selection rules. When the verb like is used to express a polite way to say what you want or to ask what somebody wants, we can use would or should: I'd like to think it over; We'd like you to come and visit us [10]. The syntactic and semantic criteria are necessary to account for the choice of complement with the verbs of liking.

Thus, these findings shed new light on the synchronic processes of the construction of gerundive utterances. The ing-complement form occurs in same-time, backward-looking and forward-looking constructions as well as in the contemplation construction type. There are three essential parameters for explaining complement usage with the ing-form: the meaning of the main verb, the meaning of the complement form and the sense of the sentence. The criteria that determine the choice of either the to-infinitive or the gerund as a complement are the meanings of sentence and the main verb, the stance of the speaker, syntactic and semantic factors. The opposition between the infinitive and the gerund is seen as the difference between a particular case and a universal sense. Verbs can be followed by the gerund and the infinitive with no change in meaning, with a change in meaning, exclusively with the gerund or the infinitive. The relation in time between the two events is a function of the lexical content of the main verb.

Further research will be focused upon the aspects of the verbalization and nominalization of the ing-form in a diachronic approach.

\section{References:}

1. Celce-Murcia M., Larsen-Freeman D. The grammar book: an ESL/ EFL teacher's course. $2^{\text {nd }}$ ed. Boston: Heinle \& Heinle, 1999. 849 p. URL: https://flaviamcunha.files.wordpress.com.

2. Dixon R. M. W. A new approach to English grammar, on semantic principles. Oxford : Clarendon Press, 1992. 398 p. URL: https:// books.google.com.ua.

3. Duffley P. J. Verbs of Liking with the Infinitive and the Gerund. Journal of English Linguistics. 2003. 31 (4). P. $324-352$.

4. Egan Thomas. Non-finite complementation: A usage-based study of infinitive and -ing clauses in English. Language and Computers: Studies in Practical Linguistics. Amsterdam-New York : Rodopi, 2008. No 65. 432 p.

5. Fonteyn L., De Smet H., Heyvaet L. What It Means to Verbalize: The Changing Discourse Functions of the English Gerund. Journal of English Linguistics. 2015. Vol. 31. Issue 1. P.36-60. URL: http://citeseerx.ist.psu.edu.

6. Gordon E. M., Krylova I. P. A Grammar of Present-Day English (Parts of Speech). Moscow : Vyssaja skola, 1980. 2 ed. 335 p.

7. Langacker R. W. Foundations of Cognitive Grammar: Descriptive applications. Berlin : Mouton de Gruyter, 1991. 628 p.

8. Norris Roy, French Amanda. Ready for Advanced : coursebook with key. 3rd ed. Macmillan exams, 2015. 280 p.

9. Norris Roy. Ready for First : coursebook with key / Roy Norris. 3rd ed. Macmillan exams, 2015. 278 p.

10. Oxford Advanced Learner's Dictionary / managing eds Margaret Deuter, Jennifer Bradbery, Joanna Turnbull. Oxford University Press, 2006. 9 ed. 1820 p.

11. Tabor Whitney, Elisabeth Closs Traugott. Structural scope expansion and grammaticalization. The limits of grammaticalization. Anna Giacalone Ramat, Paul J. Hopper (eds.). Amsterdam: John Benjamins, 1998. 229-272 p.

12. Wierzbicka Anna. The Semantics of Grammar. John Benjamins Publishing company Amsterdam/ Philadelphia, 1988. 620 p. 